\title{
Microscopic anatomy and histochemistry of the crayfish parasite Psorospermium haeckeli
}

\author{
Günter Vogt, Melanie Rug
}

Department of Zoology 1 (Morphology/Ecology), University of Heidelberg, Im Neuenheimer Feld 230, D-69120 Heidelberg, Germany

\begin{abstract}
Psorospermium haeckeli, a common parasite of the European noble crayfish Astacus astacus, occurs as an egg-shaped spore of ca $100 \times 60 \times 60 \mu \mathrm{m}$, particularly within the collagenous layer of the thoracic arteries and the surrounding subepidermal connective tissue. Smaller numbers are also found within the connective tissues of virtually all organs. The morphology and histology of these spores was investigated by microscopic techniques and the composition of their major structural components was identified by histochemistry. Each spore is enveloped by a layer of connective tissue which is assumed to derive from the host. It varies in thickness and composition among the infected organs. The spore proper consists of a 3-layered shell enclosing many globules. The outer shell layer is composed of solid, collagen- and elastin-negative, proteinaceous plates separated by sutures. The medial shell layer appears less compact and includes glycoprotens or neutral mucopolysaccharides. The inner layer is composed of 2 membranous structures including glycoproteins, glycolipids, and collagen- and elastin-like proteins. The interior of the spore contains lipid globules of variable size, intensely staining nonlipid globules with crystalline and vacuolar inclusions, and 2 closely associated nuclei. In most of the crayfish investigated some of the spores were encapsulated by haemocytes and melanized.
\end{abstract}

KEY WORDS: Psorospermium haeckeli Parasite - Astacus astacus · Crayfish · Microscopic anatomy Histochemistry

\section{INTRODUCTION}

Psorospermium haeckeli Hilgendorf, 1883 is a common parasite of freshwater crayfish which was discovered by Haeckel (1857) and described by Hilgendorf (1883). In Europe it occurs in the native species Astacus astacus (Linné, 1758) and A. leptodactylus and the introduced species Pacifastacus leniusculus and Orconectes limosus (Nylund \& Westman 1978, Alderman \& Polglase 1988). Outside Europe it was found in Louisiana, USA, in Procambarus clarkii and Procambarus zonangulus (Henttonen et al. 1992) and in Australia in Cherax tenuimanus (L. Evans, Aquaculture Research and Development Unit, Beatley, WA, Australia, pers. comm.) and C. quadricarinatus (Edgerton et al. 1995).

Although Psorospermium haeckeli has been well known for more than $100 \mathrm{yr}$, its life cycle is unknown. The parasite is found in the connective tissue of the crayfish as a shell-bearing spore with globular con- tents which develops from a smaller, membrane-bound stage (Grabda 1934, Rug \& Vogt 1994). All experiments undertaken so far to stimulate further development of the spore have failed. Therefore, at present the name $P$. haeckeli refers to the spore and its developmental stages.

The taxonomic position of Psorospermium haeckeli is also unclear. Some authors consider the parasite to be sporozoan (summarized by Alderman \& Polglase 1988) but others as the histopathogenic stage of a dimorphic fungus (Nylund et al. 1983). The potential pathogenicity of $P$. haeckeli is controversial as well. Vey (1978), Söderhäll (1988) and Kobayashi \& Söderhäll (1990) assume that the parasite can cause high mortalities in both wild and cultured populations but other investigators found no positive correlation between a high infection rate and decreased vitality or even mortality of the crayfish (Wierzejski 1888, Ljungberg \& Monné 1968, Nylund \& Westman 1978, Vranckx \& Durliat 1981, Taugbøl \& Skurdal 1992). 
Morphological comparison of Psorospermium haeckeli from crayfish species listed above indicates the existence of at least 4 morphotypes which may represent different species. These morphotypes differ from one other with respect to size, shape and appearance of the globular contents. The European noble crayfish Astacus astacus harbours either an egg-shaped spore of ca $100 \times 60 \times 60 \mu \mathrm{m}$ with internal globules of heterogenous size (Scheer 1934, Ljungberg \& Monné 1968 Nylund \& Westman 1977, Henttonen et al. 1992, Taugbol \& Skurdal 1992), or a more elongate, slightly

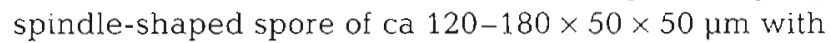
roundish or lancet-like ends, small uniform globules and a broad envelope of host connective tissue (Haeckel 1857, Grabda 1934). It is this elongate form of variable length which was originally discovered by Haeckel (1857) and named Psorospermium haeckeli by Hilgendorf (1883). Aside from $A$. astacus it was also found in A. leptodactylus (Vey 1978). The spores of the American crayfish Procambarus clarkii and Procambarus zonangulus are elongate as well and have also a broad envelope and uniform globules but have a slightly different shape and measure only ca $110 \times 45 \times$ 45 um (Henttonen et al. 1992). The smallest P. haeckeli was found in Cherax spp. in Australia (Evans pers. comm.). It has an elongate-ovoid shape, measures ca $90 \times 40 \times 40 \mathrm{\mu m}$ and includes only small globules All dimensions given refer to the spore proper and do not include the envelope of host connective tissue. An additional Psorospermium orconectis was described by Scheer (1979) from the gut lumen of Orconectes limosus. However, this spore is very similar to late developmental stages of the elongate form found in $A$. astacus (Rug \& Vogt 1995) and is most probably not a fifth morphotype

Aside from crayfish, Psorospermium sp. spores have been reported from the freshwater amphipod Gammarus lacustris (Voronin 1975) and the marine scyphozoan Lucernaria auricula (Vallentin 1888). In Gammarus lacustris from lakes of the Baikal District in Russia, ovoid spores of $110 \times 55 \mu \mathrm{m}$ were found in the connective tissue between internal organs and muscles (Voronin 1975). According to the line drawings published these spores are similar to the ovoid type of Astacus astacus with respect to their shape but differ slightly in size and contain only small uniform globules. The occurrence of Psorospermium-like spores in Lucernaria auricula was reported in a short note without drawings (Vallentin 1888), and it is questionable whether the observed objects were members of Psorospermium at all.

This report describes the architecture of the ovoid type of Psorospermium haeckeli collected from the noble crayfish Astacus astacus. The morphological description is based on fresh and $\mathrm{KOH}$-treated whole mounts and on paraffin sections stained by routine histological methods. The composition of the shell and of the globular contents was identified, or at least characterized, by a variety of histochemical tests performed with paraffin-and cryosections.

\section{MATERIALS AND METHODS}

Psorospermium haeckeli was collected in July 1993 from 10 intermoult males of the European noble crayfish Astacus astacus by scraping connective tissue together with blood vessels from the inner side of the carapace (Henttonen et al. 1992). In addition, we sampled hepatopancreas, antennal gland, gills, testes, haematopoietic tissue, heart, nerves, brain, and musculature. The crayfish used had wet weights of 80 to $110 \mathrm{~g}$, had been reared in our laboratory in $200 \mathrm{I}$ tanks for more than 1 yr without contact with fish or other aquatic animals, and had been fed exclusively on beef, unboiled spaghetti and carrot. Cannibalism occurred occasionally.

For histological evaluation we used whole mounts, cryosections and paraffin sections. Tissue mounts were investigated either fresh or after treatment with $\mathrm{KOH}$ by a macroscope (Wild M 420) and using bright field, polarisation and Nomarski differential interference

Fig. 1. Psorospermium haeckeli in various tissues and organs of Astacus astacus. (a) Thoracic arteries (arrows indicate diameter) with many refractive spores (arrowheads). $\mathrm{KOH}$-treated mount, photographed with a macroscope against bnght background; scale bar $=200 \mu \mathrm{m}$. (b) Mature and developing spores in subepidermal connectıve tissue. Fresh mount; scale bar $=50 \mu \mathrm{m}$. (c) Cross section of artery with $P$. haeckeli in collagenous adventitia. Arrow: fluorescing elastic fibres. Orcein, fluorescence microscopy; scale bar $=20 \mu \mathrm{m}$. (d) $P$. haeckeli attached to collagen of subepidermal connective tissue. Azan; scale bar $=20 \mu \mathrm{m}$. (e) $P$. haeckel assoriated with elastic fibres (arrows) of haematopoietic tissue. Orcein, fluorescence microscopy; scale bar $=20 \mu \mathrm{m}$. (f) $P$. haeckell. with thick envelope in intertubular connective tissue of hepatopancreas. H\&E; scale bar $=20 \mu \mathrm{m}$. $(\mathrm{g})$ Psorospermium (elongate morphotype!) in tip of gill filament. Fresh mount; scale bar $=50 \mu \mathrm{m}$

Abbre'siations for all figures. A: artery; AD: collagenous adventitia of artery; C: collagen fibres, CT: connective tissue; DS: developing spore: E: envelope; G: globule; GH: granular haemocyte; HC: haemocytic capsule; HT: hepatopancreas tubule; I: intuma of blood vessel; IL: inner shell layer; IS: inner space of spore; L: lumen of blood vessel; LG: lipid globule; ML: medial shell layer; MP: melanized P. haeckeli; MS: mature spore; N: nucleus; NG: nonlipid globules; P: P. haeckelli PC: primary capsule; S: shelli SC: secondary capsule; SP: shell plates 


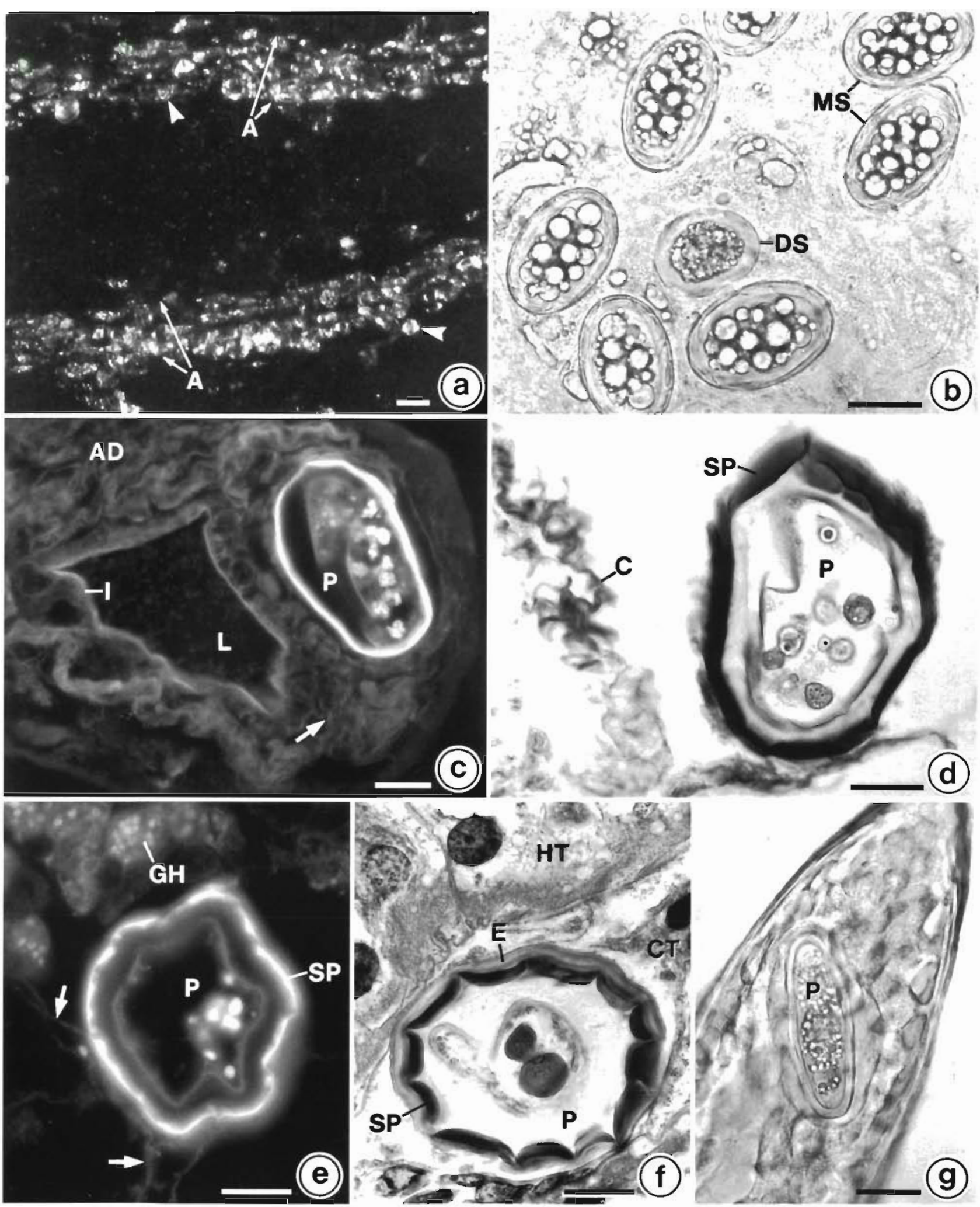


contrast microscopes (Leitz Aristoplan). KOH-treatment (e.g. $0.1 \mathrm{M}$ for $10 \mathrm{~h}$ ) dissolves the host connective tissue partly or completely, depending on the concentration and time of exposure, and facilitates detection and investigation of the parasites. Cryosections, ca $6 \mu \mathrm{m}$ thick, were prepared with a Reichert-Jung Frigocut 2700 for demonstration of lipids. They were fixed for 2 min with $50 \%$ ethanol, stained with Sudan black B, counterstained with nuclear fast red and examined immediately with a bright-field microscope. The samples for paraffin sectioning were fixed with Susafixative (Böck 1989) for 24 h, dehydrated through a graded series of ethanol, transferred to methylbenzoate overnight and then embedded in paraffin. Sections of $5 \mu \mathrm{m}$ were deparaffinized in xylene, transferred through graded ethanol and treated with $1 \%$ Lugol's iodine for $10 \mathrm{~min}$ and $0.25 \%$ aqueous sodium thiosulfate for $5 \mathrm{~min}$ to remove mercury precipitates from fixation. Thereafter, the slides were stained either with H\&E, Goldner's and Cason's trichrome stains for general histological analysis, or with Heidenhain's Azan for collagen, PAF-Halmi (Adam \& Czihak 1964), Weigert's Resorcin-fuchsin and Verhoeff's method for elastin and collagen, Orcein for elastin, Gomori's silver impregnation for reticulin fibres, Alcian blue-alcian yellow for sulfated and carboxylated acid mucopolysaccharides (Bancroft \& Stevens 1990), and PAS for glycoproteins, neutral mucopolysaccharides, and glycolipids. All procedures were carried out according to Böck (1989) if not indicated otherwise. Examination of the stained paraffin sections was done with a bright field microscope. Cason's-, Resorcin-fuchsin- and Orcein-stained sections were additionally inspected with a fluorescence microscope using a Leitz filter block I $2 / 3$.

\section{RESULTS}

\section{Distribution in organs and tissues}

Spores of Psorospermium haeckeli are generally associated with the connective tissue. They are found throughout the body in greater or lesser numbers depending on the location of the connective tissue. By far the greatest number are located in the wall of the dorsal thoracic arteries (Fig. 1a) which lead off from the heart towards the head. These arteries include thousands of parasites within the compact adventitia (Fig. 1c) which is composed of collagen and elastic fibres. The site with the second highest amount of spores is the subepidermal connective tissue underneath the carapace (Fig. 1b) which extends from the epidermis to the haematopoietic tissue on the roof of the cardiac stomach. This tissue is made up of collagen fibres which are preferred attachment sites of the parasite (Fig. 1d). Fewer spores occur along the elastic fibres of the haematopoietic tissue (Fig. 1e), in the connective tissue of the hepatopancreas (Fig. 1f), and in the gills. In the latter they are preferably located at the tips of the filaments (Fig. $1 \mathrm{~g}$ ). Only a few individual spores are found associated with the antennal gland, testes, nerves, brain and musculature. The heart is always free of parasites.

\section{Major structural components}

The ovoid spore of Psorospermium haeckeli measures on average approximately $100 \times 60 \times 60 \mu \mathrm{m}$. It is composed of a ca $10 \mu \mathrm{m}$ thick shell and globular contents (Fig. 2a, d, e). The shell is divided into 3 layers: an outer layer made up of irregular plates of variable size (Fig. 2a to c), a broader medial layer (Fig. 2d, e), and a narrow inner layer which is composed of 2 membranelike structures (Figs. 2e \& 3f). The interior contains 1 pair of small, closely associated nuclei (double nucleus) of ca $6 \mu \mathrm{m}$ (Fig. $4 \mathrm{a}$ to $\mathrm{c}$ ) and 2 types of globules, lipid globules of variable size up to $30 \mu \mathrm{m}$ (Fig. 2f) and nonlipid globules of ca $15 \mu \mathrm{m}$ (Fig. 2g). Each spore is surrounded by an envelope of host connective tissue (Fig. 2d) which is more evident in stained sections (Fig. 3a, b) than in whole mounts.

\section{Histochemical characterization}

The components of Psorospermium haeckeli listed below were characterized by a variety of routine histological stains and more specific histochemical tests. It has to be emphasized that the techniques used were originally developed for vertebrate tissues. Therefore, a positive reaction does not necessarily indicate the presence of substances which are biochemically identical to those of vertebrate tissues. It does indicate, however, the presence of material with similar histochemical properties. The major results of the stainings are compiled in Table 1

The envelope around the spore varies considerably among the host tissues with respect to thickness and histochemical composition. It is always thin $(<0.5 \mu \mathrm{m})$ in the network of elastic fibres of the haematopoietic tissue (Fig. 1e) and thick (2 to $4 \mu \mathrm{m}$ ) in the hepatopancreas (Fig. 1f). The envelope is composed of 2 layers which can be distinguished by several stains. The outer layer is positive for collagen when stained by Azan (Fig. 3a), Goldner's (Fig. 3b), PAF-Halmi (Fig. 3d), Cason's (Fig. 4c) and Verhoeff's techniques. It fluoresces brightly with Resorcin-fuchsin (Fig. 3e) which facilitates a clear recognition of its form and diameter. The inner layer of 



Fig. 2. Psorospermium haeckeli. Morphology. Scale bars $=20 \mu \mathrm{m}$. (a) Fresh spore focused slightly below the surface displaying shell plates with connecting sutures (arrow) and many globules in the interior. (b) Susa-fixed and Cason's-stained P. haeckeli with numerous smaller shell plates. Arrow denotes blindly ending suture. (c) Susa-fixed and Goldner's-stained spore composed of few, larger shell plates. (d) Bright field image of typical fresh spore focused into the centre with narrow envelope of connective tissue, broad shell and inner space with globules of heterogenous size. (e) Nomarski differential interference contrast image of fresh spore demonstrating subdivision of shell into 3 layers: outer layer of solid shell plates, broad medial layer (asterisk) and inner layer with 2 membrane-like structures (arrow). (f) Cryosection stained with Sudan black B to identify lipid globules. Arrowhead indicates lipid staining of membranous structures of inner shell layer. Shell plates counterstained with nuclear fast red. (g) Susa-fixed and Goldner's-stained paraffin section displaying intensely staining nonlipid globules with crystalline inclusions and vacuoles. Lipid globules were extracted by dehydration with ethanol 





Table 1 Psorospermium haeckeli. Histological and histochemical characterization of major structural components. -: negative; +: weakly or partly positive ++ : strongly positive

\begin{tabular}{|c|c|c|c|c|c|c|c|c|c|}
\hline & $\begin{array}{c}\text { Collagen-like } \\
\text { proteins }\end{array}$ & $\begin{array}{c}\text { Elastin-like } \\
\text { proteins }\end{array}$ & $\begin{array}{l}\text { Basic } \\
\text { proteins }\end{array}$ & $\begin{array}{l}\text { Acid } \\
\text { protelns }\end{array}$ & $\begin{array}{l}\text { Glycoproteins, } \\
\text { glycolipids } \\
\text { neutral muco- } \\
\text { polysaccharides }\end{array}$ & $\begin{array}{l}\text { Acid mucopoly- } \\
\text { saccharides }\end{array}$ & Lipids & $\begin{array}{l}\text { Silver } \\
\text { staining }\end{array}$ & $\begin{array}{l}\text { Polari- } \\
\text { sation }\end{array}$ \\
\hline Envelope & ++ & ++ & + & - & ++ & - & - & + & - \\
\hline Shell plates & + & - & ++ & + & + & - & - & + & ++ \\
\hline Medial shell layer & + & + & - & - & t+ & - & - & - & - \\
\hline Inner shell layer & ++ & ++ & - & - & ++ & + & + & ++ & - \\
\hline Lipid globules & - & - & - & - & - & - & ++ & - & - \\
\hline Nonlipid globules & - & - & + & ++ & + & - & - & - & + \\
\hline Double nucleus & - & - & ++ & + & - & - & - & - & - \\
\hline Nucleoli & - & - & + & ++ & - & - & - & - & - \\
\hline
\end{tabular}

the envelope, which can be thin (Fig. 4c), stains intensely with PAF-Halmi (Fig. 3d) and PAS (Fig. 3f) indicating a composition of elastin-like proteins and glycoproteins or neutral mucopolysaccharides.

The shell plates stain intensely with most procedures and are bi-refringent under the polarisation microscope indicating a symmetric arrangement of their sub-components. They are particularly well demonstrated by fluorescences related to Orcein (Figs. 1c, e \& 3c) and Resorcin-fuchsin (Fig. 3e). With Goldner's (Fig. 3b) they stain brown, and red with H\&E (Fig. 4a), Cason's (Fig. 4c) and Azan (Fig. 3a) suggesting that they include basic non-collagen and non-elastin proteins. Collagen-like proteins are found in a thin rim around each plate (Fig. 3b) as demonstrated with Azan and Goldner's (Fig. 3b). Staining with PAF-Halmi (Fig. 3d) exposes a subdivision of the plates into 3 sublayers which are brown, yellow and green. At least the middle one of these sublayers is PAS-negative (Fig. 3f). Heterogeneities within the plates are visible in Resorcin-fuchsin-stained sections (Fig. 3e).

The medial shell layer is often torn apart in paraffin sections (Fig. 3f) and remains unstained or weakly stained in almost all procedures. Only with Azan, PAFHalmi and PAS is there a moderate to strong positive reaction for collagen (Fig. 3a), elastin (Fig. 3d) and neutral mucopolysaccharides (Fig. 3f), respectively. The double-membraned inner shell layer stains intensely for collagen (Fig. 3a), elastin (Fig. 3d) and glycoproteins/glycolipids (Fig. 3f), and moderately for lipids (Fig. 2f) and carboxylated acid mucopolysaccharides. The respective dyes are particularly confined to the 2 membrane-like structures. This innermost shell layer is additionally impregnated with silver which indicates a fibrillar subarchitecture.

The lipid globules are visible only on cryosections stained with Sudan black B (Fig. 2f). In paraffinembedded material they are extracted during processing. The nonlipid globules stain intensely with a wide variety of stains (Figs, $2 g, 3 a, b \& 4 a$ to $c$ ). Quite often, they stain similarly to but not entirely like the nuclei. They appear orange to brown with Goldner's, red with Azan and Cason's, violet with H\&E, and yellow with PAF-Halmi. This staining pattern indicates a high protein content of the nonlipid globules which does not include collagen- and elastin-like proteins. Sometimes they are also PAS-positive (Fig. 3f). After staining with Orcein (Fig. 3c) and Cason's (Fig. 4d) they fluoresce brightly yellow or red, respectively.

The double nucleus (Fig. 4a to d) is easily identified using Cason's stain (Fig. 4c) since its violet colour is in sharp contrast to the orange to red colour of the nonlipid

Fig. 3. Psorospermium haeckeli. Histology and histochemistry. Scale bars $=10 \mu \mathrm{m}$. (a) Azan-stained cross section displaying collagen-positive structures: envelope, medial shell layer and double-membraned inner shell layer. Note large nonlipid globules with vacuoles (white arrow). Black arrow denotes continuity of outer collagenous envelope with host connective tissue. (b) Goldner's-stained cross section illustrating composition of envelope of collagen-positive outer layer (arrowhead) and negative inner layer (arrow). The shell plates are enclosed by a narrow rim of collagen-like material (open arrows). (c) Orcein-stained cross section showing strong fluorescence of shell plates and nonlipid globules (arrow). (d) PAF-Halmi-stained cross section indicating abundance of elastin-like proteins in envelope and inner shell layer. The shell plates (diameter marked by arrows) appear subdivided into 3 layers. Arrowhead: collagenous outer rim of envelope. (e) Resorcin-fuchsin-stained cross section showing heterogeneities in fluorescing shell plates (arrow) and fluorescence of outer rim of envelope (arrowhead). (f) PAS-stained cross section with positive reaction of inner layer of envelope, medial shell layer (arrowhead), inner shell layer and nonlipid globules. The interior of the shell plates is PAS negative (arrow). Note disruption of medial shell layer 




Fig. 4. Psorospermium haeckeli. Double nucleus. Scale bars $=20 \mu \mathrm{m}$. (a) Longitudinal, H\&E-stained section with nonlipid globules and 2 closely associated nuclei with nucleoli (arrowhead). (b) High magnification of Goldner's-stained double nucleus with diffuse chromatin and distinct nucleoli (arrowhead) and nonlipid globules with vacuoles (arrow). (c) and (d) Corresponding Cason's-stained bright field and fluorescence micrographs showing double nucleus with fluorescing nucleoli (arrows). Arrowhead: fluorescing nucleolus of host cell

globules. Its structural features and its structural differences from the nonlipid globules are best demonstrated by Goldner's stain (Fig. 4b). The 2 nuclei which stain the same as the host nuclei, including the red fluorescence of their nucleoli (Fig. 4c, d), are of relatively uniform size (ca $6 \mu \mathrm{m}$ ) and have diffuse chromatin and a prominent nucleolus. In mature spores, the nonlipid globules are always larger than the nuclei, include unstained vacuoles (Fig. 4b) and, sometimes, bi-refringent crystals Serial sections of numerous spores revealed that each spore contains only 1 double nucleus.

The matrix of the interior of the spore is always only weakly stained and displays no prominent histochemical characteristics.

\section{Encapsulation and melanization}

The degree of encapsulation and melanization of Psorospermium haeckeli in the 10 crayfish investigated varied from $0 \%$ (1 specimen) to $>50 \%$ (1 specimen; Fig. 5a). In most crayfish, only a small percentage of the spores were attacked by host defenses. Encapsulation starts with accumulation of haemocytes around the spore and formation of a cellular capsule (Fig. 5b, e). In early stages of encapsulation the content of the spores appears largely unchanged (Fig. 5b) but later, particularly when melanization occurs, the globules undergo degenerative changes (Fig. $5 \mathrm{c}$ ). At the end, $P$. haeckeli is enclosed in a dense, deeply black capsule (Fig. 5d). In 


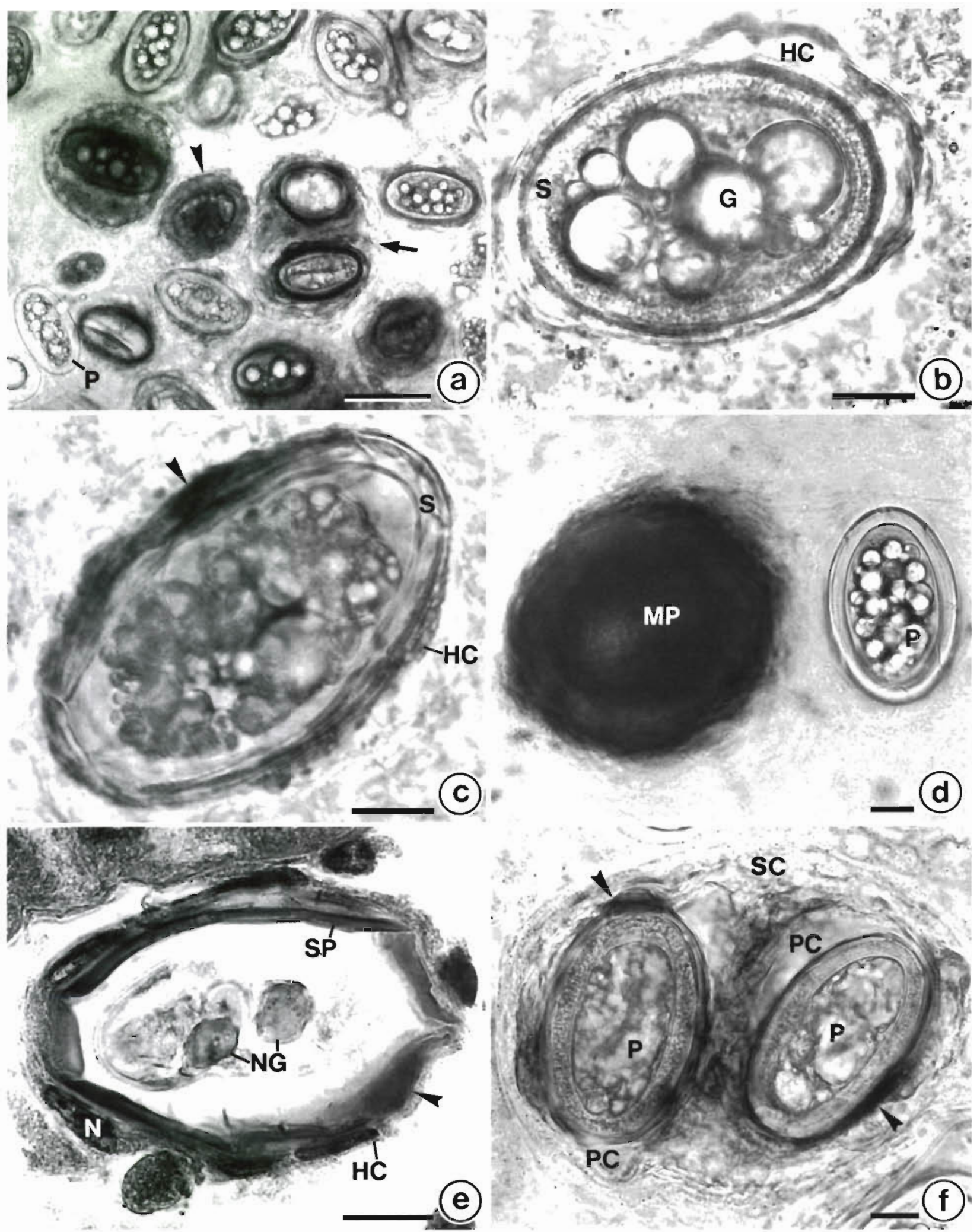

Fig. 5. Psorospermium haeckeli. Encapsulation and melanization. (a) Normal, encapsulated and melanized (arrowhead), and hyperencapsulated (arrow) P. haeckeli. KOH-treated mount. Scale bar $=100 \mu \mathrm{m}$. (b) Haemocytic capsule around spore with largely intact interior. Fresh mount; scale bar $=20 \mu \mathrm{m}$. (c) Encapsulated and partly melanized (arrowhead) parasite with degenerating interior. Fresh mount; scale bar $=20 \mu \mathrm{m}$. (d) Normal and completely melanized $P$. haeckeli. Fresh mount; scale bar $=$ $20 \mu \mathrm{m}$. (e) Paraffin section of encapsulated and melanized (arrowhead) spore. H\&E; scale bar $=20 \mu \mathrm{m}$. (f) Hyperencapsulated spores surrounded by primary and secondary capsules of haemocytes and melanized spots (arrowheads). KOH-treated mount; 
crayfish with an intensive response 2 or more encapsulated and melanized spores can be hyperencapsulated by haemocytes (Fig. 5a, f). This mechanism creates large black nodules in the infected tissues.

\section{DISCUSSION}

Investigation of major organs and tissues of Astacus astacus revealed that the spores of the crayfish parasite Psorospermium haeckeli are particularly abundant within the compact collagenous layer of the dorsal thoracic arteries. A close association of $P$. haeckeli with blood vessels was earlier observed by Haeckel (1857), Scheer (1934) and Nylund \& Westman (1978). The second highest number of spores was found in the subepidermal connective tissue underneath the carapace, whereas connective tissues associated with other organs harboured only few spores. This finding is consistent with data published by Haeckel (1857), Scheer (1934), Nylund \& Westman (1978), Vey (1978) and Henttonen et al. (1992). Based on this distribution pattern it is recommended that the subepidermal connective tissue underneath the carapace, inclusive of its blood vessels, should be sampled to diagnose the level of $P$. haeckeli infection in crayfish. Sampling is most easily achieved by scraping of this tissue from the inner side of the raised carapace as suggested by Henttonen et al. (1992).

The principal structural components of Psorospermium haeckeli, a 3-layered shell, lipid globules, nonlipid globules, and 2 closely associated nuclei, and also the surrounding envelope of host connective tissue, were recognized by early investigators (e.g. Grabda 1934). The present histological and histochemical results obtained by investigation of the ovoid spores from Astacus astacus enable a more detailed characterization of these components.

The outer envelope of the ovoid spores differs con siderably among infected tissues with respect to thickness, density and histochemical composition, suggesting that it is derived from the host in response to the parasite, as earlier proposed by Wierzejski (1888) and Grabda (1934). This envelope, which remained unstained or weakly stained with most routine stains (Wierzejski 1888, Grabda 1934), can be well demonstrated with stains for collagen, elastin and glycoproteins. It is composed of an outer rim of collagen-like proteins and an inner layer of elastin-like proteins and mucosubstances. The abundance of neutral mucopolysaccharides in the envelope was also reported by Vey (1978). The envelope seems to confine the parasite within the host tissue. It does not appear to be an impermeable barrier for nutrients since it occurs already around growing spores (Rug \& Vogt 1994).
Furthermore, it does not totally prevent foreign-body recognition by the host since in most of our crayfish a few percent of the spores were encapsulated by haemocytes and melanized as also observed by Vranckx \& Durliat (1981) and Cerenius et al. (1991).

The shell of the spore is composed of 3 ctistinct layers, an outer layer with shell plates, a broad medial layer, and an inner layer with a double-membraned structure which contains the globules. This observation is consistent with the literature, although some authors count the envelope as a fourth layer (Nylund \& Westman 1978, Alderman \& Polglase 1988) or subdivide the innermost layer into 2 layers (Nylund et al. 1983, Nylund 1986). The high affinity of the shell plates for various stains, which was also observed by Wierzejski (1888) and Zacharias (1888), suggests that the shell plates include considerable amounts of protein but not collagen and elastin. A high protein content of the plates was also claimed by Vey (1978). Other authors assumed that the plates may be composed mainly of cellulose (Nylund et al. 1983), an idea that was first presented by Wierzejski (1888). Wierzejski obtained a positive reaction with the iodine and sulfuric acid test for cellulose but this finding has not been corroborated, either with the same or with more sophisticated techniques. Nylund \& Westman (1995) recently analysed the plates by SEM energy dispersive $\mathrm{x}$-ray microanalysis (EDS) and found no silica, calcium or phosphorus. Exposure of the spores to nitric acid did not destroy the shell, which led the authors to conclude that proteins are not significant to the durable structure of the plates and that cellulose may be their major component. The results of Nylund \& Westman (1995) are not necessarily contradictory to ours since the plates could contain both proteins and cellulose. However, convincing direct proof for the presence of cellulose in the shell plates is still lacking.

The medial shell layer is often torn apart in paraffin-embedded spores suggesting that it is softer than the other layers. Grabda (1934) described this layer as gelatinous and observed that it swells in water This property may be related to the abundance of mucopolysaccharides and may be essential in releasing the contents of the spore to continue the parasitic life cycle. The narrow inner layer is composed of 2 membrane-like structures. Staining for lipids, glycoproteins/glycolipids, elastin, collagen and carboxylated acid mucopolysaccharides, and additional silver impregnation, indicates that this layer is not just an array of 2 membranes but a more complicated structure. Electron microscopy (Vey 1978. Nylund et al. 1983, Nylund 1986, present study) seems to corroborate this interpretation but does not contribute further significant data due to the insufficient resolution of this layer 
The presence of lipid globules in Psorospermium haeckeli was demonstrated by early investigators by means of lipid histochemistry (Grabda 1934, Scheer 1934) and later corroborated by electron microscopy (Vey 1978, Nylund \& Westman 1983). The lipid globules of the ovoid form of $P$. haeckeli are very variable and measure up to $30 \mu \mathrm{m}$. In the living spores they have a fluid consistency. They are thought to function as energy stores.

In contrast to the lipid globules, the identity of the ca $15 \mu \mathrm{m}$ large nonlipid globules is still obscure. They stain intensely with many dyes (Grabda 1934, Vey 1978) and often include crystals and vacuoles. Due to the latter features they could be interpreted as autophagosomes. However, they have a dense and compact matrix which often stains like the chromatin of the nuclei. Such a staining behaviour is not consistent with autophagosomes. It rather suggests that these globules may be generative stages of Psorospermium haeckeli which are released in a later phase of the developmental cycle. Unfortunately, no further details could be resolved so far by means of electron microscopy (Vey 1978, Nylund \& Westman 1983, present study)

The double nucleus is a further, rather curious feature of Psorospermium haeckeli. It was already described by Grabda (1934) and photographically documented in whole mounts by Nylund \& Westman (1983). We have found such closely associated nuclei only in late developing and mature spores (Rug \& Vogt 1994. 1995) but not in early stages as described by Grabda (1934). Staining of the nuclei is easy in paraffin sections but seems difficult in whole mounts (Grabda 1934). Each of the 2 nuclei is considerably smaller than those of the host tissues and has diffuse chromatin and a distinct nucleolus.

Aside from the double nucleus, lipid globules and nonlipid globules, the spores of Psorospermium haeckeli contain mitochondria, ribosomes and glycogen as revealed by electron microscopy (Vey 1978, Nylund \& Westman 1983).

Histological and histochemical investigations of Psorospermium haeckeli contributed significantly to the understanding of the architecture of the parasite but did not clarify its taxonomic identity. It is clear that $P$. haeckeli is an eucaryotic organism, but it is still an open question whether it is a fungus, an alga or a protozoan. The plant hypothesis is supported by the lack of movement within the spore and similarities of the spore's architecture to conidia of the histopathogenic fungus Blastomyces dermatitidis (Rippon 1980) as emphasized by Nylund \& Westman (1983). Further contributions to the resolution of the taxonomic position of $P$. haeckelican be expected from electron microscopic investigations and molecular analysis of the parasite. Regarding electron microscopy, the quality of fixation first requires enhancement. We are presently trying to achieve better fixation of early developmental stages since such stages lack a shell which hinders fast penetration of the fixatives into the interior.

Acknowledgements. We thank Gisela Adam for excellent reproduction of the micrographs and Dr Walter Stocker and Danny Köhler for providing some of the Psorospermiuminfected crayfish.

\section{LITERATURE CITED}

Adam H, Czihak G (1964) Arbeitsmethoden der makroskopischen und mikroskopischen Anatomie. Gustav Fischer Verlag, Stuttgart

Alderman DJ, Polglase JL (1988) Pathogens, parasites and commensals. In: Holdich DM, Lowery RS (eds) Freshwater crayfish. Biology, management and exploitation. Croom Helm, London, p 167-212

Bancroft JD, Stevens A (eds) (1990) Theory and practice of histological techniques. Churchill Livingstone, Edinburgh

Böck P (1989) Romeis, Mikroskopische Technik, 17. Auflage. Urban \& Schwarzenberg, München

Cerenius L, Henttonen P, Lindqvist OV, Söderhäll K (1991) The crayfish pathogen Psorospermium haeckeli activates the prophenoloxidase activating system of freshwater crayfish in vitro. Aquaculture 99:225-233

Edgerton B, Owens L. Harris L, Thomas A (1995) Health survey of farmed Redclaw, Cherax quadricarinatus, in tropical Australia. Freshwater Crayfish 10: in press

Grabda E (1934) Recherches sur un parasite de l'écrevisse (Potamobius fluviatilis L.) connu sous le nom de Psorospermium haeckeli Hlgd. Mém Acad Pol Sci Lett, Cracovie, Sér B 6:123-142

Haeckel E (1857) Ueber die Gewebe des Flusskrebses. Arch Anat Physiol Med (Müller's Archiv) 24:469-568

Henttonen P, Lindqvist OV, Huner JV (1992) Incidence of Psorospermium sp. in several cultivated populations of crayfishes, Procambarus spp. (Decapoda, Cambaridae), in Southern Louisiana. .J World Aquacult Soc 23:31-37

Hilgendorf $F$ (1883) Bemerkungen über die sogenannte Krebspest, insbesondere über Psorospermum Haeckelii spec. nova. Sitzungsber Gesellsch naturforsch Freunde Berlin 9:179-183

Kobayashi M, Söderhäll K (1990) Comparison of concanavalin A reactive determinants on isolated haemocytes of parasite-infected and non-infected freshwater crayfish. Dis aquat Org 9:141-147

Ljungberg O, Monné $L$ (1968) On the eggs of an enigmatic nematode parasite encapsulated in the connective tissue of the European crayfish, Astacus astacus in Sweden. Bull Off int Epiz 69:1231-1235

Nylund V (1986) Ravun loisen, Psorospermium haeckeli Hilgendorf rakenne, haittavaikutukset ja taksonominen asema. Riista- ja kalatalouden tutkimuslaitos, kalantutkimusosasto. Monistettuja julkaisuja 55:1-60

Nylund V, Westman K (1977) Psorospermium haeckeliravun loistauti loydetty Suomesta. Suomen Kalastuslehti $7: 162-165$

Nylund V, Westman K (1978) Psorospermium haeckeli, a parasite on the European crayfish, Astacus astacus, found in Finland. Freshwater Crayfish 4:385-390

Nylund V, Westman K (1995) On the chemical structure and 
taxonomic position of the crayfish parasite Psorospermium haeckel Hilgendorf. Freshwater Crayfish 10: in press

Nylund V. Westman K, Lounatmaa K (1983) Ultrastructure and taxonomic position of the crayfish parasite Psorospermium haeckeli Hilgendorf. Freshwater Crayfish 5: $307-314$

Rippon JW (1980) Dimorphism in pathogenic fungi. CRC Crit Rev Microbiol 8:49-97

Rug M. Vogt G (1994) Developmental stages of the crayfish parasite Psorospermium haeckeli in thoracic arteries of Astacus astacus. J Invertebr Pathol 64:153-155

Rug M, Vogt G (1995) Histology and histochemistry of developing and mature spores of two morphotypes of Psorospermium haeckeli. Freshwater Crayfish 10: in press

Scheer D (1934) Über einen mutmaßlichen Blutgefäßparasiten des Flußkrebses (Potamobius astacus). Z Parasitenkde 6:478-480

Scheer D (1979) Psorospermium orconectis n. sp., ein neuer Parasit in Orconectes limosus. Arch Protistenkde 121. $381-391$

Söderhäll K (1.988) Fungal parasites and other diseases on

Responsible Subject Editor: J. E. Stewart, Dartmouth, N.S., Canada freshwater crayfish. In: Kovanen J, Lappalainen R (eds) Raputalous 2000, Keskı-Suomen Kalastuspiin Kalastustoimisto. Tiedotus, Jyváskylä, Finland, 5:23-46

Taugbol T, Skurdal J (1992) Parasitten Psorospermium haeckeli påvist i norske krepsebestander. Fauna 45:32-39

Vallentin R (1888) Psorospermium Lucernariae. Zool Anz 11:622-623

Vey A (1978) Recherches sur une maladie des écrevisses due au parasite Psorospermum haeckeli Hilgendorf. Freshwater Crayfish 4:411-4.18

Voronin VN (1975) On findings of Psorospermium sp. in Gammarus lacustris. Izvest gos nauc-issl Inst ozernogo i recnogo rybnogo Choz (Leningrad) 93:125-126 (in Russian with English abstract)

Vranckx R, Durliat M (1981) Encapsulation of Psorospermium haeckeli by the haemocytes of Astacus leptodactylus. Experientia 37:40-42

Wierzejski A (1888) Kleiner Beitrag zur Kenntnis des Psorospermium Haeckelii. Zool Anz 11:230-231

Zacharias O (1888) Über Psorospermium Haeckelii. Zool Anz 11:49-51

Manuscript first received: August 18, 1994

Revised version accepted: November 14, 1994 